\title{
Fire and edge effects in a fragmented tropical forest landscape in the southwestern Amazon
}

\author{
Izaya Numata $^{\mathrm{a}, *}$, Sonaira S. Silva ${ }^{\mathrm{b}}$, Mark A. Cochrane ${ }^{\mathrm{c}}$, Marcus V. d’Oliveira ${ }^{\mathrm{d}}$ \\ ${ }^{a}$ Geospatial Sciences Center of Excellence, South Dakota State University, Brookings, SD 57006, USA \\ ${ }^{\mathrm{b}}$ Campus Floresta, Universidade Federal do Acre, Rio Branco, Brazil \\ ' Appalachian Laboratory, University of Maryland Center for Environmental Sciences, Frostburg, MD 21532, USA \\ ${ }^{\mathrm{d}}$ EMBRAPA Acre, Rio Branco, Acre, Brazil
}

\section{A R T I C L E I N F O}

\section{Article history:}

Received 11 April 2017

Received in revised form 5 July 2017

(c) 2017 Elsevier B.V. All rights reserved.

Accepted 8 July 2017

\section{Introduction}

The Amazon holds the largest tropical rain forest formation in the world but this natural ecosystem has been altered by both anthropogenic and natural disturbances since the 1970s (Davidson et al., 2012). The Brazilian Amazon experienced the highest annual tropical deforestation rates until the mid-2000s when rates began to decline dramatically due to the government's environmental law enforcement. Conversely, other forest disturbances, such as understory fire, selective logging, and fragmentation (Aragao et al., 2014; Arima et al., 2014) have gained more importance in terms of their impacts on remnant forests. The degree of forest degradation varies as functions of disturbance type, the intensity and frequency of disturbance events, and the time since occurrence (Cochrane and Schulze, 1999; Barlow and Peres, 2004; Brando et al., 2014). Additionally, the impacts of these disturbances may vary across the region due to different gradients of physical conditions including rainfall, edaphic and geological properties (Hoorn et al., 2010; Malhi et al., 2004).

Despite the drastic decline of the annual deforestation rates in the Brazilian Amazon in recent years, the occurrence of fire has not decreased (Tasker and Arima, 2016). Burned forests become more flammable and vulnerable to subsequent drought events compared to undisturbed forest (Cochrane and Laurance, 2008). Depending upon future land use and resulting forest disturbance, Amazonian ecosystems could become much more vulnerable to drought impacts, increasing regional fire susceptibility (Davidson et al., 2012). As for forest fragmentation, forest biomass and species

\footnotetext{
* Corresponding author.

E-mail addresses: izaya.numata@sdstate.edu (I. Numata), sonairasilva@gmail. com (S.S. Silva), mark.cochrane@umces.edu (M.A. Cochrane), marcus.oliveira@ embrapa.br (M.V. d'Oliveira).
}

composition are known to be vulnerable to edge effects in Amazonia (Laurance et al., 2011; Berenguer et al., 2014; Benchimol and Peres, 2015). These changes in forest structure and composition changes occurred close to forest edges. Edge effects are highly variable in space and time and edge phenomena vary within the same habitat fragment and landscape due factors such as edge age, edge aspect, and multiple edges (Laurance et al., 2006, 2007). Their combination with different biophysical conditions make edge effects even more variable.

These disturbances are prevalent in the arc of deforestation, the southern and eastern Amazon. Forests in the southwestern Amazon are especially subject to high impacts from forest fragmentation (Numata and Cochrane, 2012) and forest fires associated with drought events (Aragao et al., 2007; Alencar et al., 2015). Forest responses to disturbances in southwestern Amazonia seem different from those in other regions of the basin. While high rates of tree mortality, up to $50 \%$, caused by fires have been reported in central and eastern Amazonia, more modest impacts of fire on tree mortality have been found in the southwestern Amazon (Barlow et al., 2012). Intense biophysical changes such as forest biomass loss and structural change occur within a short distance from edges (e.g., 100-300 m) during the first years after edge creation (Lovejoy et al., 1986; Laurance et al., 1997). Different responses to forest fragmentation have been observed regionally. Unlike the strong edge effects on forest biomass found in the central Amazon (Laurance et al., 1997), research conducted in the southwestern Amazon observed no significant edge effects (Phillips et al., 2006). These differences are potentially related to nutrient rich soils and forest types with faster recovery rates, resulting in greater resilience to disturbances in this region (Malhi et al., 2004; Phillips et al., 2006; Barlow et al., 2012). However, the impacts of and forest responses to disturbances in the southwestern region are still poorly studied. 
In the southwestern Amazonian state of Acre, intense deforestation in recent decades has made forests in unprotected areas highly fragmented (Cumming et al., 2012; Numata and Cochrane, 2012). This region has also been one of the epicenters of severe drought events in 2005 and 2010 (Lewis et al., 2011; Davidson et al., 2012), which triggered extensive forest fires across the state. Here, we examine the impacts of forest fire and fragmentation on forest biomass and structure in Acre. We addressed two objectives in our study: (1) the characterization of post-fire forest recovery from wildfires in 2005 and 2010; and (2) analysis of edge effects on forest aboveground biomass (AGB) and stem density in different tree size classes in five fragmented forest areas. To accomplish these objectives, we sampled two different environments: (1) forests burned in 2005 and 2010; and (2) unburned forest areas subject to variable degrees of forest fragmentation in Acre.

\section{Study sites and methods}

\subsection{Study area}

The study was focused on the eastern side of Acre (Fig. 1) where intensive forest cover change has occurred and remnant forests are highly fragmented. In 2010 , nearly $30 \%$ of remaining forests in the state were within $1 \mathrm{~km}$ from forest edges (Numata and Cochrane, 2012), and the percentage is much greater in eastern Acre. Forest types include open tropical forest with bamboo, open forest with palm trees and lianas, and dense tropical forests (forests with a uniform canopy and emergent trees) (Acre, 2010). The climate is Awi (Köppen), with annual precipitation of approximately $2000 \mathrm{~mm}$ and an average temperature of $25^{\circ} \mathrm{C}$. The dry season occurs between the months of June and September. The area has topography dominated by gently sloping hills. The predominant soils are dystrophic yellow Latosols with high clay content (Amaral, 2006).

\subsection{Mapping forest fragmentation and fire}

We utilized Landsat time series data (Path/row: 1/67 and 2/67) to develop annual forest fragmentation and fire data. First, we created annual land cover data using the method developed by Souza et al. (2013) that combines spectral mixture analysis and binary decision classification. From this dataset, burned forests in 2005 and 2010 were also identified. Forest fragmentation data including edge distance (the distance from the forest border) and edge age (time since fragmentation) relative to 2014, were estimated (Fig. 2). Distance of each pixel to the nearest forest in forest areas was calculated based upon Euclidian distance (edge distance map), whereas the edge age map of 2014 was generated using the same land cover time series data for the 1997-2014 period following the methods of Numata et al. (2009, 2011).

\subsection{Forest inventory}

Forest inventories were conducted from July to August 2014. The study sites included one in a forest reserve area (Reserva Bonal, F1) and four within forest fragments situated in private properties (F2 to F5) (Fig. 1). Forest inventories in these sites include forest burned in 2005 and 2010 and unburned areas. The forest reserve has been under a sustainable development project led by the Institute of Agricultural Reform and Colonization (INCRA). All sites were located within a distance of $67 \mathrm{~km}$. We established thirty-two 500-m transects across the study region. To establish transects for forest inventories in fragmented forests, we selected areas where forest edges are clearly defined and consist of straight lines and avoided fuzzy edge zone with irregular shapes, while transects were established in forests edges near roads within the reserve. Each transect was designed to contain six $25 \mathrm{~m} \times 25 \mathrm{~m}$ plots in every $100 \mathrm{~m}$ starting from forest edge up to $500 \mathrm{~m}$ into interior of forest (Fig. 3). However, due to occasional events, such as forest fires undetected by our

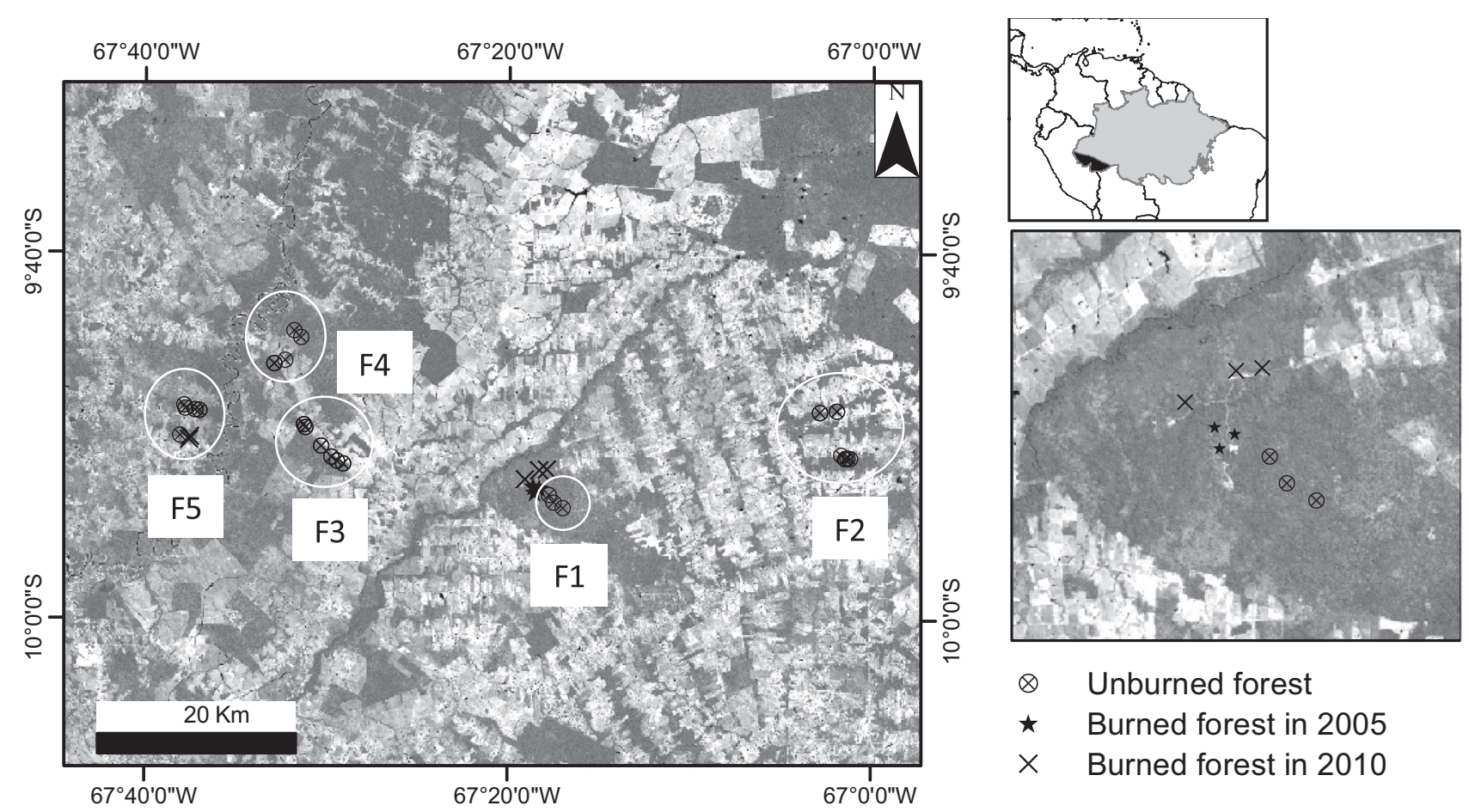

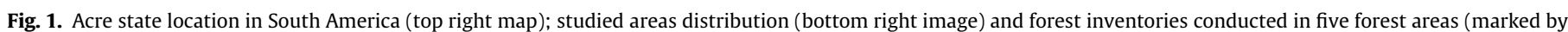

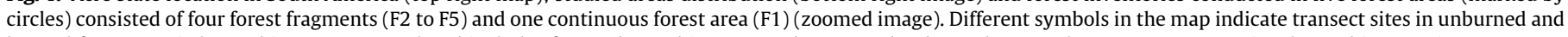
burned forests. F1 is located in Reserve Bonal and includes forests burned in 2005 and 2010, and unburned areas. There are two more sites burned in 2010 in F5. 
(a) Edge distance

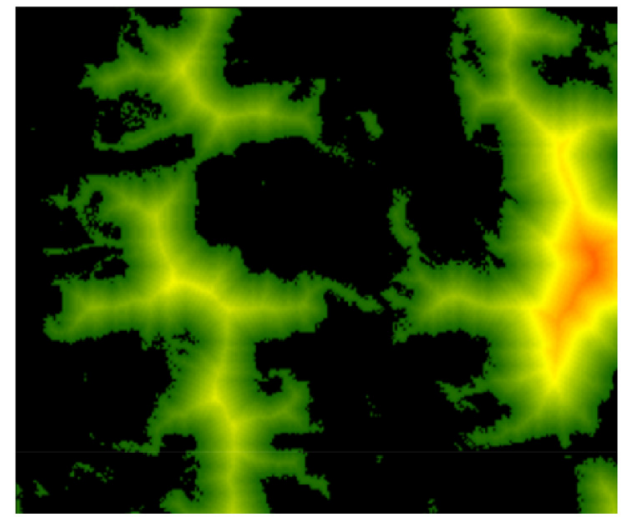

(c) Edge Density

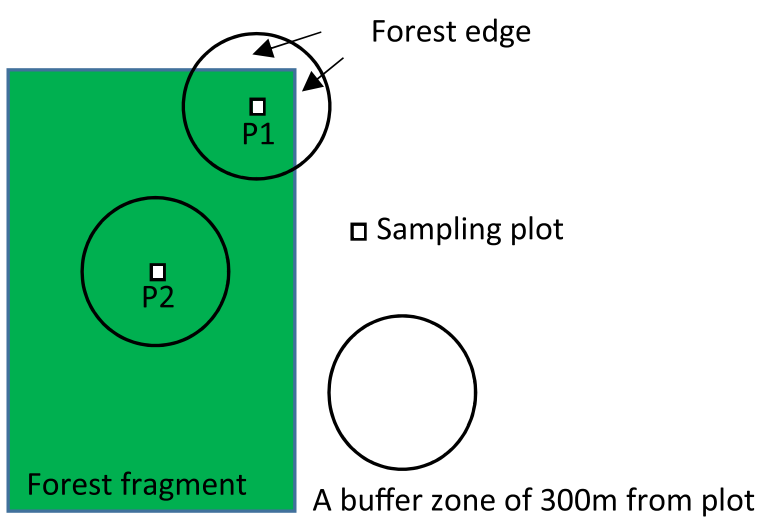

(b) Edge Age

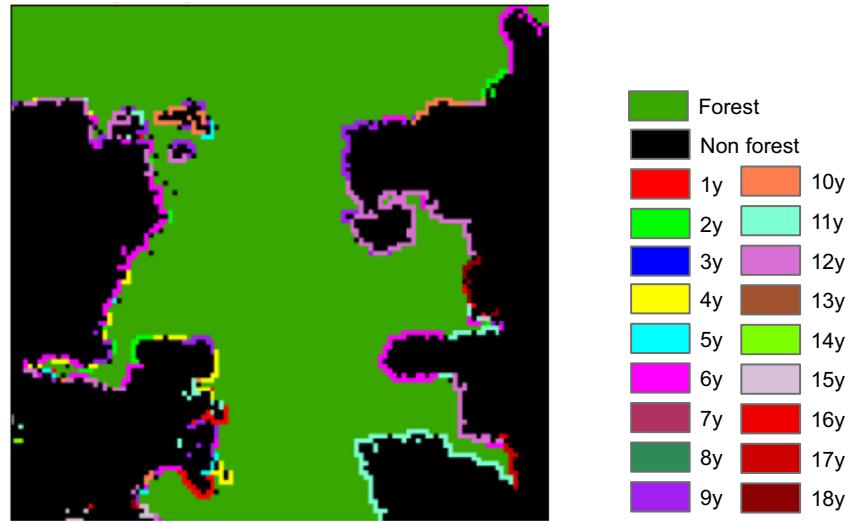

(d) \% Forest Area

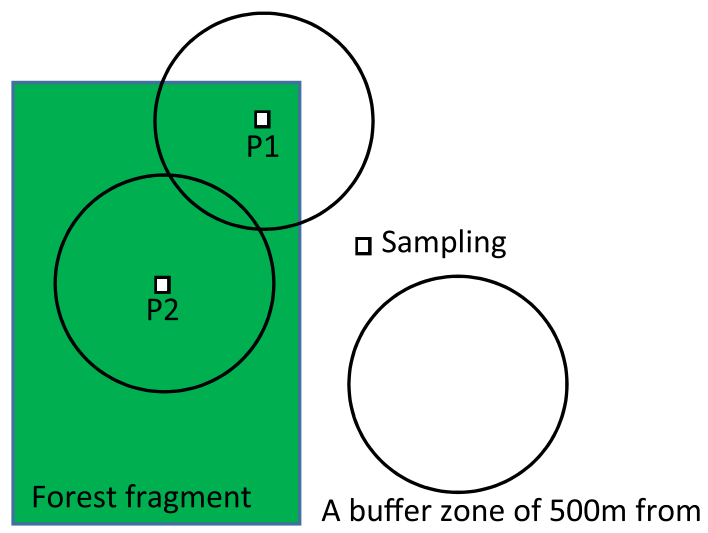

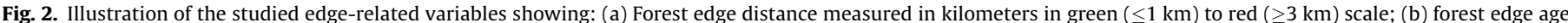

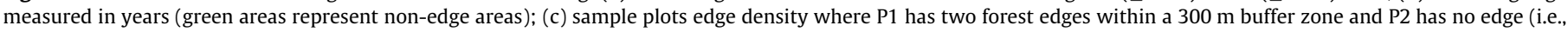

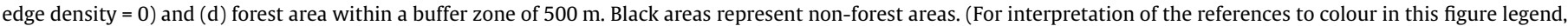
the reader is referred to the web version of this article.)
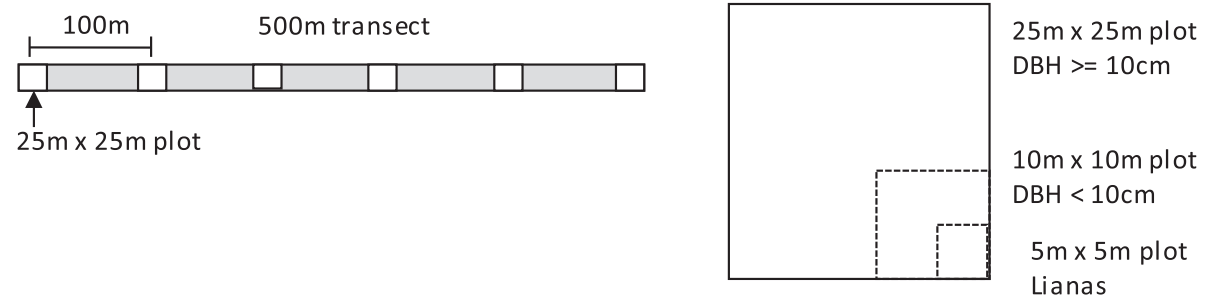

Fig. 3. Illustration of the $500 \mathrm{~m}$ transect with the $25 \mathrm{~m} \times 25 \mathrm{~m} ; 10 \mathrm{~m} \times 10 \mathrm{~m}$ and $5 \mathrm{~m} \times 5 \mathrm{~m}$ sub-plots.

image inspection, five transects had less than six plots. In total, $12725 \mathrm{~m} \times 25 \mathrm{~m}$ plots ( $14.25 \mathrm{ha}$ ) were sampled over unburned forests and 54 plots were sampled in burned forests, of these plots, 18 plots in the forest burned in 2005 and 36 plots in the forests burned in 2010. Our study plots of "unburned" forests were distributed across five forest areas.

All stems with $\mathrm{DBH} \geq 10 \mathrm{~cm}$ were measured within the $25 \times 25$ plots. Within each plot, we set subplots of $10 \mathrm{~m} \times 10 \mathrm{~m}$ and of $5 \mathrm{~m} \times 5 \mathrm{~m}$ to sample stems with $\mathrm{DBH}<10 \mathrm{~cm}$ and lianas, respectively (Fig. 3). Sampled stems were classified as live or dead and botanically identified to species or higher taxon (genus or family) level by two botanists. With this data, species richness, the number of different species in each plot, was also estimated.
Stems were subdivided into pioneer and non-pioneer classes. The pioneer species identified in the study areas are summarized in Table 1. Cecropia sp. has been used to indicate disturbances and its recovery process in the tropics (Uhl et al., 1988; Scatena et al., 1993; d'Oliveira and Ribas, 2011) and accounted for 35\% of the pioneer species group in our study areas (Table 1). Therefore, we used this species as a disturbance indicator in this study. AGB was estimated for all stems by applying an allometric equation (Nogueira et al., 2008) developed for forest types in the southwestern Amazon that has been used in Acre by d'Oliveira et al. (2012) and Andersen et al. (2013). For palm species, we used a family-level allometric equation developed by Goodman et al. (2013). We quantified only the number of dead trees per 
Table 1

Total number and relative density of pioneer species individuals identified in the burned and unburned study areas in Acre State, southwestern Amazon.

\begin{tabular}{lll}
\hline Species & Number & $\%$ \\
\hline Apeiba membranacea & 46 & 3.4 \\
Bauhinia spp. & 13 & 1.0 \\
Bixa urucurana & 322 & 23.7 \\
Carica microcarpa & 38 & 2.8 \\
Cecropia spp. & 477 & 35.1 \\
Cochlospermum orinocense & 23 & 1.7 \\
Colubrina glandulosa & 17 & 1.3 \\
Erythrina amazonica & 27 & 2.0 \\
Piper spp. & 30 & 2.2 \\
Sapium marmieri & 19 & 1.4 \\
Schefflera morototoni & 15 & 1.1 \\
Stryphnodendron pulcherrimum & 21 & 1.5 \\
Urera spp. & 71 & 5.2 \\
Vismia spp. & 154 & 11.3 \\
Zanthoxylum rhoifolium & 34 & 2.5 \\
Other species less than 1\% of the pioneer species group & 53 & 3.9 \\
\hline
\end{tabular}

area. For pioneer species Cecropia sp., we adopted the equation of Nelson et al. (1999) for biomass estimation. We also measured tree density (number of trees per ha).

\subsection{Statistical analysis}

The effects of forest fire and fragmentation on forest structure were assessed based upon differences in AGB and stem density in four different DBH size classes: $10-20 \mathrm{~cm}, 20-30 \mathrm{~cm}, 30-$ $40 \mathrm{~cm}, 40-50 \mathrm{~cm}$, between disturbed (burned or fragmented) and undisturbed forest by one-way ANOVA with post hoc Tukey tests $(p<0.05)$.

To better understand dynamics patterns in AGB within fragmented forests, we assessed the environmental impacts and edge-related variables on forest AGB and stem density for DBH size $\geq 10 \mathrm{~cm}$ and $<10 \mathrm{~cm}$ classes. Edge-related variables associated with forest fragmentation included edge distance and edge age determined as in the previous section. Distance to nearest forest edge from each plot was determined based upon the edge distance map. The density of forest edge or edge density and the percent of total forest area surrounding a sample plot were included (Fig. 2c and d). These two additional variables were included to address multiple edge effects (Malcolm, 1994; Laurance et al., 2006) and surrounding forest area (Ewers et al., 2007), respec-
Table 2

Number of plots $(\mathrm{N})$, mean above ground biomass (AGB - $\mathrm{Mg} \mathrm{ha}^{-1}$ ), tree density (trees ha ${ }^{-1}$ ), species richness and pioneer species relative density of the studied unburned (UF) and burned in 2005 and 2010 forests in Acre State southwestern Amazon. Numbers between brackets following means indicate standard deviation $(\mathrm{p}<0.05)$.

\begin{tabular}{llll}
\hline & UF $(\mathrm{N}=127)$ & BF 2005 $(\mathrm{N}=18)$ & BF 2010 (N = 36) \\
\hline $\begin{array}{l}\text { Live AGB }\left(\mathrm{Mg} \mathrm{ha}^{-1}\right) \\
\text { Tree density (trees/ha) }\end{array}$ & $236.6(105.1)$ & $196.5(147.4)$ & $154.5(102.9)$ \\
$\quad$ & 1237.80 & 1060.44 & 1112.42 \\
$\quad$ Live & 13.48 & 45.33 & 25.26 \\
$\quad$ Dead & $32.0(12.5)$ & $25.8(8.3)$ & $25.7(10.3)$ \\
Species richness & 3.30 & 19.25 & 30.71 \\
Pioneer species (\%) & & &
\end{tabular}

tively. Edge density was determined as the number of forest edges within a 300 buffer area from each plot, whereas the percent of total forest area was estimated as the proportion (\%) of forest area within a buffer area surrounding a sample plot (Fig. 2c and d). For the latter variable, we tested two different buffer sizes: $500 \mathrm{~m}$ and $1000 \mathrm{~m}$ radius. These two variables were estimated using the landcover map of 2014. Besides these fragmentation variables, elevation and slope, as environmental variables, were estimated from $30 \mathrm{~m}$ resolution ASTER Global Digital Elevation map (GDEM V2). We assumed climate was constant across the studied sites, thus this variable was not included in our analysis.

Multi-collinearity among variables was examined using Variance Inflation Factors (VIF). VIFs $>3$ and correlation $r>0.7$ indicate that variables are highly correlated with other variables (Zuur et al., 2009). In this process, forest area within a $1000 \mathrm{~m}$ radius circle was eliminated from the analysis. All other variables had $\mathrm{VIF}<3$ and were retained in the subsequent analyses.

We used generalized linear mixed-effect models (GLMMs) to evaluate the impacts of these variables on AGB and structure in fragmented forests. GLMMs are useful for the analysis of grouped data. As our sample plots are located in different fragments, the nested sampling design was taken into account by setting "fragment" as a random effect. Through GLMMs, all possible combinations of the explanatory variables were tested to rank them by their Akaike Information criterion correction (AICc) weights. The relative importance of each explanatory variable was calculated by summing the AICc weights of all models that included the variable of interest. All statistical analyses were performed with the $\mathrm{R}$ 3.2.1. version.

Besides the above analysis, we calculated relative changes in AGB at each plot along edge distance normalized by mean AGB

Table 3

Most abundant species from the $\geq 10 \mathrm{~cm}$ and $<10 \mathrm{~cm}$ DBH classes in unburned (UB) and burned forests in 2005 and 2010 .

\begin{tabular}{|c|c|c|c|c|c|}
\hline \multirow[t]{2}{*}{ Species } & \multirow[t]{2}{*}{ Family } & \multirow{2}{*}{$\begin{array}{l}\text { Forest type for most } \\
\text { abundant species }\end{array}$} & \multicolumn{3}{|c|}{ Number of stems/ha } \\
\hline & & & UB & 2005 & 2010 \\
\hline \multicolumn{6}{|l|}{$\geq 10 \mathrm{~cm} \mathrm{DBH}$} \\
\hline Pseudolmedia laevis (np) & Moraceae & UB & 43 & 5 & 13 \\
\hline Tetragastris altissima (np) & Arecaceae & UB & 28 & 4 & 10 \\
\hline Euterpe precatoria (np) & Strelitziaceae & UB & 16 & 12 & 13 \\
\hline Cecropia sp. (p) & Urticaceae & $2005 / 2010$ & 10 & 66 & 24 \\
\hline Urera sp. (p) & Sapindaceae & 2005 & 2 & 28 & 0 \\
\hline Allophylus floribundus (np) & Arecaceae & 2005 & 2 & 25 & 0 \\
\hline Phenakospermum guyannense (np) & Burseraceae & 2010 & 26 & 13 & 139 \\
\hline \multicolumn{6}{|l|}{$<10 \mathrm{~cm} \mathrm{DBH}$} \\
\hline Guadua spp. (np) & Poaceae & 2005 & 83 & 282 & 87 \\
\hline Rinorea viridifolia (np) & Violaceae & UB & 44 & 2 & 0 \\
\hline Pseudolmedia laevis (np) & Moraceae & UB & 34 & 2 & 8 \\
\hline Gellesia gorarema (np) & Mimosaceae & 2005 & 0 & 23 & 0 \\
\hline Inga sp. (np) & Fabaceae & UB & 31 & 20 & 18 \\
\hline Baixa urucarana (p) & Pixaceae & 2010 & 0 & 2 & 136 \\
\hline Cecropia sp. (p) & Urticaceae & 2010 & 2 & 10 & 108 \\
\hline
\end{tabular}

$\mathrm{p}=$ pioneer species; $\mathrm{np}=$ nonpioneer species. 

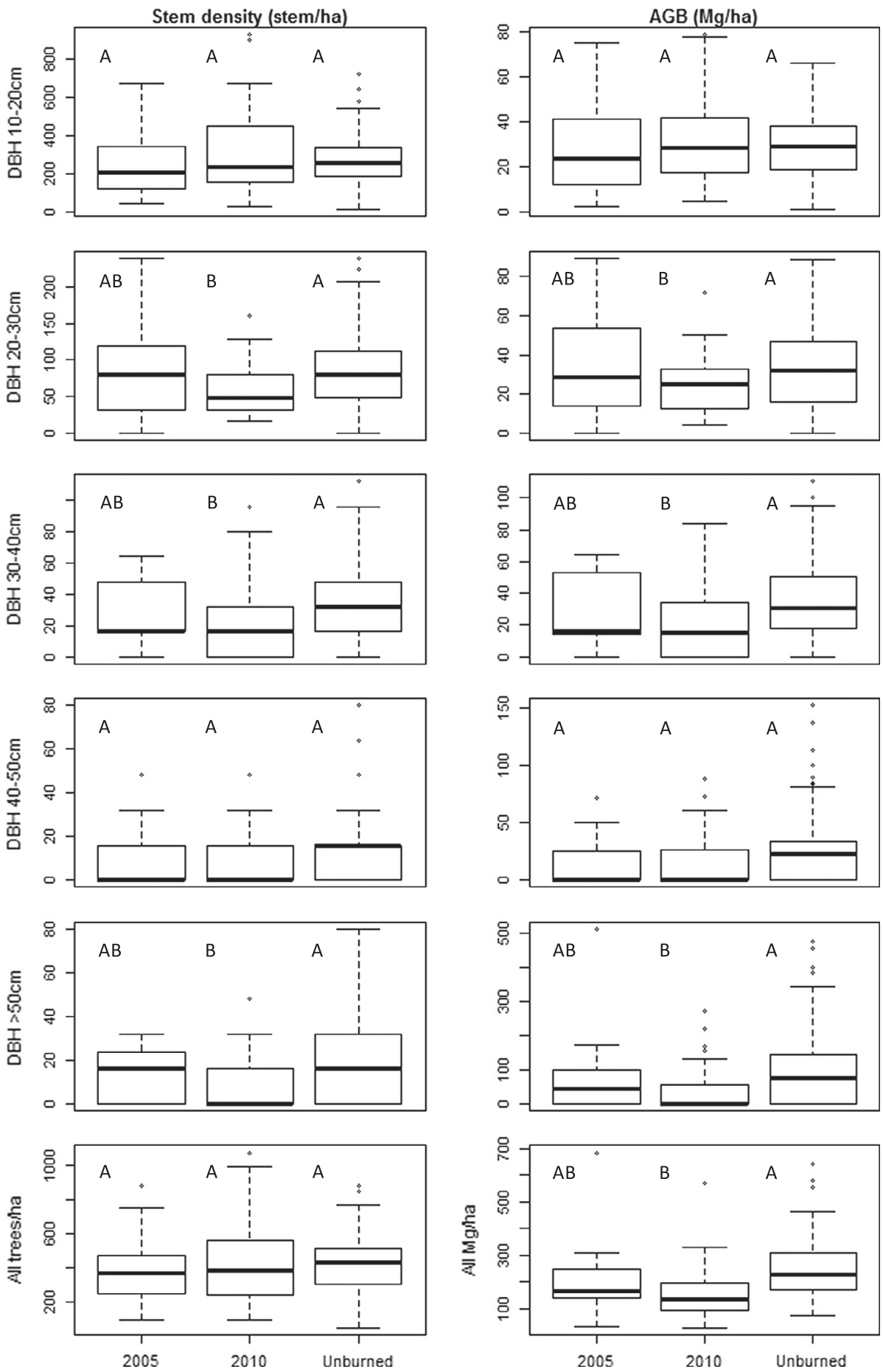

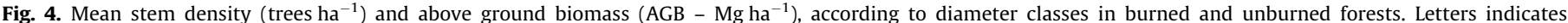
significantly different means (Tukey post hoc tests, $\mathrm{p}<0.05$ ).

of plots at $500 \mathrm{~m}$, the longest edge distance, of each fragment. Because the F5 site was small and highly fragmented there were no sample plots at $500 \mathrm{~m}$, therefore we used mean AGB of plots at $400 \mathrm{~m}$ to calculate relative AGB changes of the plots at different edge distances $<400 \mathrm{~m}$.

In this study, the interactions between forest fire and forest fragmentation on forest changes were not assessed due to a constrained sample design, as most sample plots of burned forests (2005 and 2010) are located in F1, an unfragmented forest reserve. Therefore, we analyzed the impacts of these two forest disturbance types separately.

\section{Results}

\subsection{Impacts of forest fire}

The 2010 burned forest showed the lowest amount of standing live AGB $\left(154.53 \pm 102.86 \mathrm{Mg} \mathrm{ha}^{-1}\right), 23 \%$ and $34 \%$ lower than in forests burned in 2005 and undisturbed forests, respectively (Table 2) and significantly different from unburned forest $(p<0.05)$. Conversely, the highest relative density of pioneer species was found in the most recent burned forest (30\%), followed by the 2005 burned site (19\%), and unburned forest (3.3\%). The 

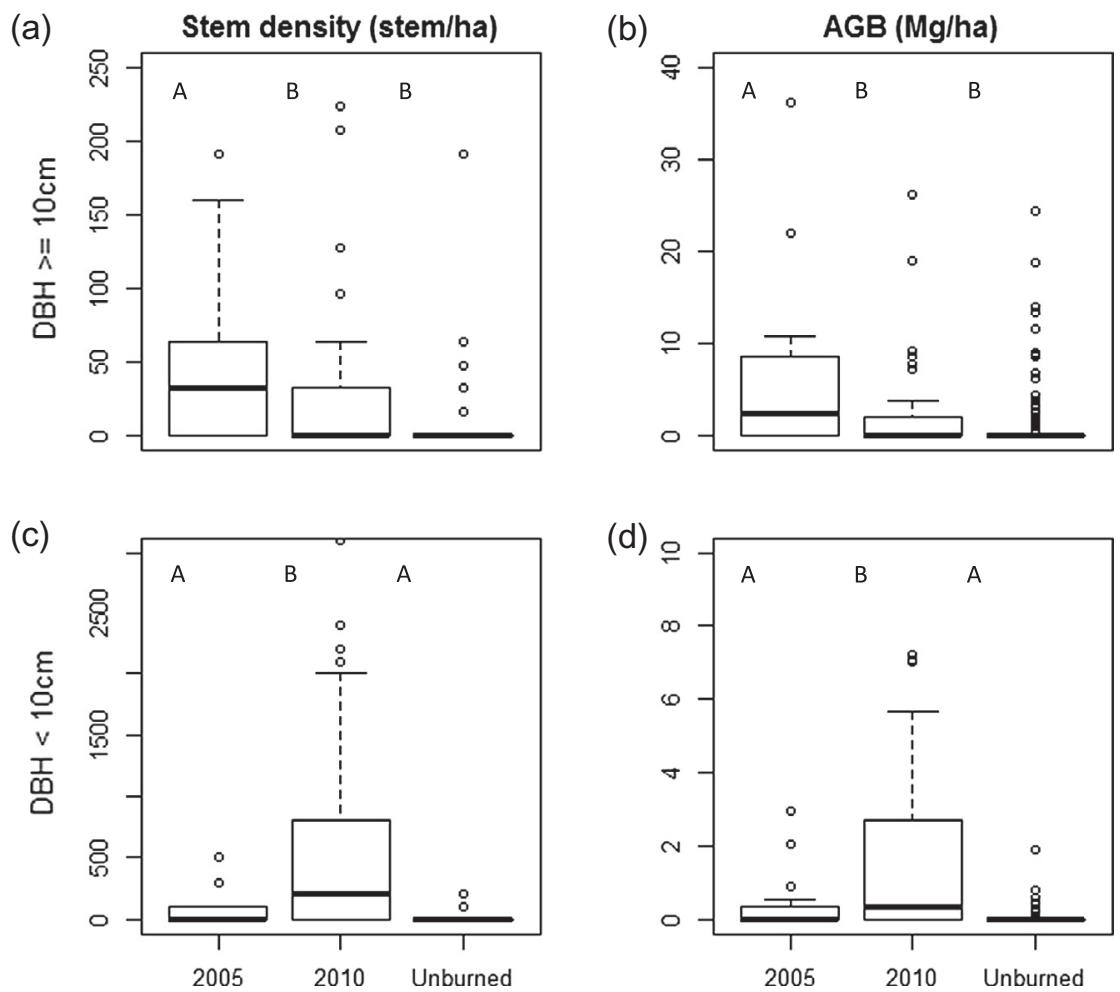

Fig. 5. Cecropia spp. mean stem density (trees ha ${ }^{-1}$ ) and above ground biomass ( $\mathrm{GGB}-\mathrm{Mg} \mathrm{ha}^{-1}$ ), according to diameter class in unburned and burned forests.

Table 4

Summary of the studied forest fragments attributes. First numbers in the cells indicate means and the numbers between brackets are standard deviations $(\mathrm{p}<0.05)$.

\begin{tabular}{|c|c|c|c|c|c|}
\hline & $\mathrm{N}$ & Distance (m) & ED & F-area (\%) & Age (year) \\
\hline \multicolumn{6}{|c|}{ Unburned forest } \\
\hline F2 & 36 & $212(145)$ & $1.28(0.74)$ & $74.5(17.8)$ & $7.2(1.7)$ \\
\hline F4 & 22 & 205 (158) & $1.09(0.92)$ & $70.6(27.9)$ & $8.9(5.7)$ \\
\hline F5 & 23 & $198(114)$ & $1.43(0.66)$ & $65.6(15.3)$ & $14.6(3.2)$ \\
\hline
\end{tabular}

$\mathrm{N}=$ number of plots; Distance = edge distance; $\mathrm{ED}=$ edge density within $300 \mathrm{~m}$ buffer from plot; F-area = the proportion of forest area in a $500 \mathrm{~m}$ radius circle with plot at the center; and Age = edge age.

2005 burned forest site had the highest number of dead trees followed by the 2010 and unburned sites (Table 2). However, relative amounts of dead trees to live trees are small, accounting for only $1.0 \%, 4.3 \%$ and $2.3 \%$ in unburned, 2005 and 2010 burned forests, respectively. Unburned forest showed the highest species richness, whereas burned forests in 2005 and 2010 have almost the same number of species (Table 2).

In terms of species composition differences among the burned and unburned sites, most abundant species from $\geq 10 \mathrm{~cm}$ DBH are non-pioneer species for unburned forest, while more pioneer species such as Cecropia sp. and Urera sp. were found in the 2005 burned forest (Table 3). High density of Phenakospermum guyannense was found in the 2010 burned forest, followed by Cecropia sp. P. guyennense is characteristic of recently burned areas (Xaud et al., 2013). Within the $<10 \mathrm{~cm}$ DBH size class, high densities of bamboo (Guadua spp.) were found in both burned and unburned forests but strongly dominated in the 2005 burned forests. Nonpioneer species typified unburned forests, whereas the 2010 burned forest was dominated by pioneer species such as Baixa urucurana and Cecropia sp. in the smaller diameter class. Forests burned in 2005, showed increased prevalence of non-pioneer and decreased prevalence of pioneer species as compared to the 2010 burned forests.
AGB and stem density among unburned and burned forests were not significantly different in the DBH $10-20 \mathrm{~cm}$ size class (Fig. 4). For all studied size classes, no significant difference was found between the forest area burned in 2005 and the unburned forest for both stem density and stand AGB. The area burned in 2010 presented significantly lower stem density and AGB than the other areas in the size classes $20-30 \mathrm{~cm}, 30-40$ and $>50 \mathrm{~cm}$ $(p<0.05)$. Overall, AGB and stem density present the same patterns of changes across size classes. For overall aboveground biomass, with DBH above $10 \mathrm{~cm}$, significant difference remained between unburned and forests burned in 2010, while the three forest areas presented no significant differences in overall stem density.

Cecropia sp., a disturbance indicator, showed rapid growth after fire events in our study areas, with burned forests presenting higher stem density of this species than unburned forests. The largest AGB and stem density of Cecropia sp. with $\mathrm{DBH} \geq 10 \mathrm{~cm}$ was found in the 2005 forests, with significant differences with both 2010 burned and unburned forests $(p<0.05$ and $p<0.01$, respectively, Fig. $5 \mathrm{a}$ and b). In contrast, smaller size ( $\mathrm{DBH}<10 \mathrm{~cm}$ ) Cecropia sp. was most much more prevalent in recently burned forests (2010) than either 2005 burned forests or unburned areas $(p<0.01$ for both, Fig. $5 c$ and $d)$. 

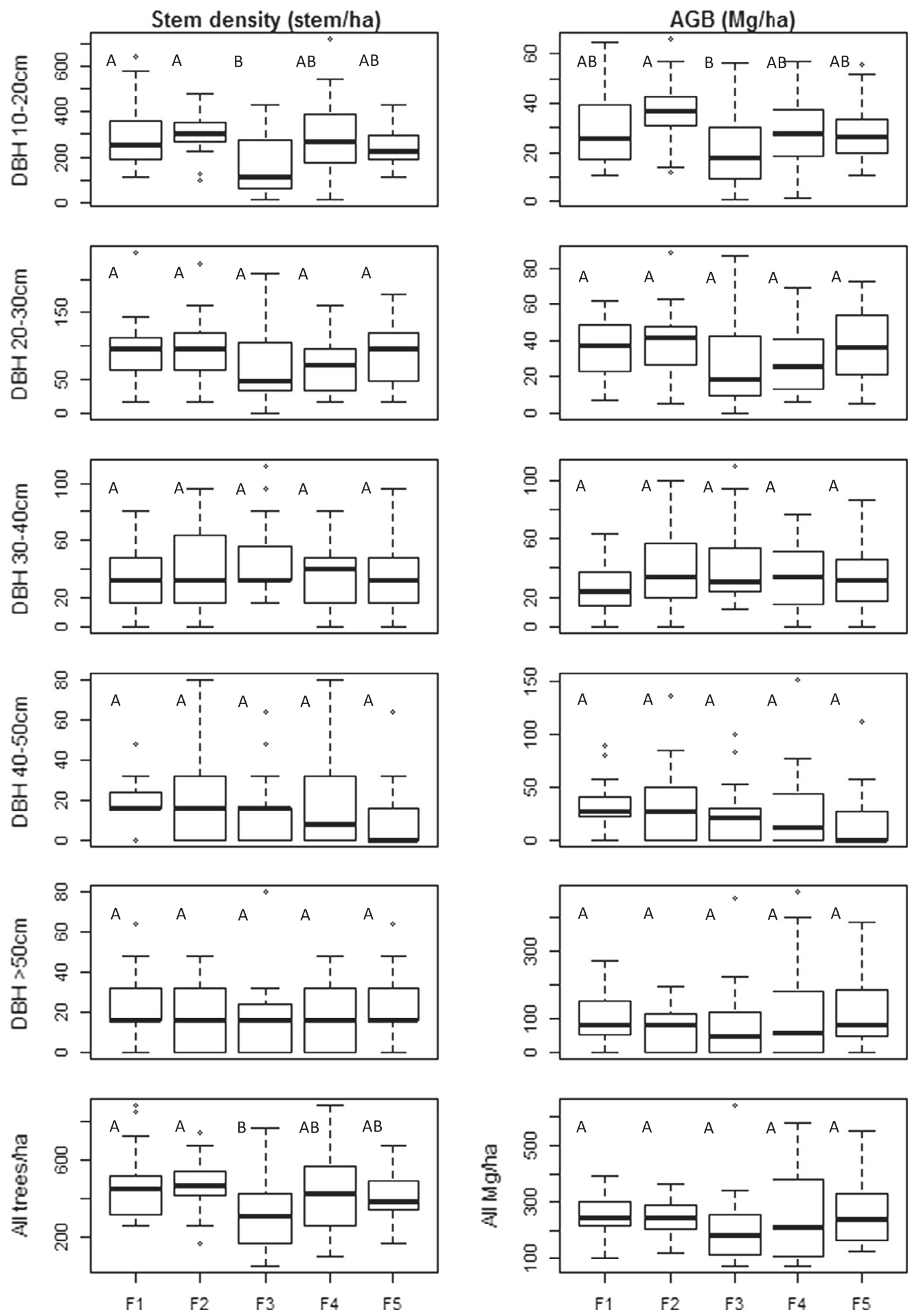

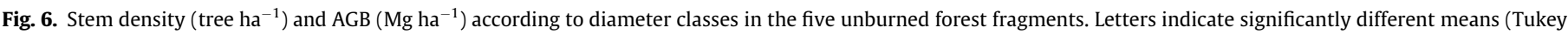
post hoc tests, $\mathrm{p}<0.05)$.

Table 5

Mean pioneer species density (trees $\mathrm{ha}^{-1}$ ), pioneer species (PS) relative density and Cecropia relative density in the pioneer species group in the fragmented sites in Acre.

\begin{tabular}{llll}
\hline & PS density (stems/ha) & \% of PS & \% of Cecropia \\
\hline F1 & 52.21 & 4.45 & 24.20 \\
F2 & 26.22 & 2.01 & 45.76 \\
F3 & 52.74 & 4.19 & 15.73 \\
F4 & 34.91 & 3.14 & 16.67 \\
F5 & 48.70 & 3.54 & 37.14 \\
\hline
\end{tabular}

\subsection{Impacts of forest fragmentation}

The five study sites present variable forest fragmentation characteristics (Table 4). Among these sites, F1 is the least fragmented site with the longest average edge distance, smallest edge density and the largest forest area within a $500 \mathrm{~m}$ buffer from each plot. These edges are also the most recently created ( 2.7 years old). By contrast, F5 is the most fragmented area, characterized by the shortest average edge distance, largest edge density and smallest 
Table 6

Summary of best-fit GLMM models for the dependent variables forest above ground biomass (AGB), tree density ( $\mathrm{DBH} \geq 10 \mathrm{~cm}$ and $\mathrm{DBH}<10 \mathrm{~cm}$ ) and Cecropia relative density, and edge-relate variables (age, distance, density and forest area) in the fragmented forest sites.

\begin{tabular}{|c|c|c|c|c|}
\hline Dependent & Models & & p-value & $\mathrm{R}^{2}$ \\
\hline \multicolumn{5}{|l|}{ AGB } \\
\hline \multicolumn{5}{|l|}{$\mathrm{DBH} \geq 10 \mathrm{~cm}$} \\
\hline \multirow[t]{2}{*}{ Tree } & Age & -0.0307 & $0.0433^{*}$ & 0.09 \\
\hline & $\mathrm{ED}$ & -0.1597 & 0.064 & \\
\hline \multirow[t]{2}{*}{ Cecropia sp. } & F-area & -0.2132 & $0.006^{* *}$ & 0.11 \\
\hline & ED & -3.7540 & $0.009^{* *}$ & \\
\hline \multicolumn{5}{|l|}{$\mathrm{DBH}<10 \mathrm{~cm}$} \\
\hline Tree & Slope & 0.03739 & 0.1158 & 0.01 \\
\hline Cecropia sp. & Age & -0.0113 & $0.02^{*}$ & 0.01 \\
\hline \multicolumn{5}{|l|}{ Stem density } \\
\hline \multicolumn{5}{|l|}{$\mathrm{DBH} \geq 10 \mathrm{~cm}$} \\
\hline \multirow[t]{2}{*}{ Tree } & Age & -0.0569 & $0.004^{* *}$ & 0.12 \\
\hline & F-area & -0.0109 & $0.017^{*}$ & \\
\hline \multirow[t]{3}{*}{ Cecropia sp. } & F-area & -0.5349 & $0.001^{* *}$ & 0.11 \\
\hline & Age & -1.1220 & $0.036^{*}$ & \\
\hline & Distance & 0.0423 & 0.062 & \\
\hline \multicolumn{5}{|l|}{$\mathrm{DBH}<10 \mathrm{~cm}$} \\
\hline \multirow[t]{3}{*}{ Tree } & Elevation & 0.0039 & 0.078 & 0.13 \\
\hline & Slope & 0.0658 & $0.011^{*}$ & \\
\hline & Age & -0.0163 & $0.004^{* *}$ & \\
\hline Cecropia sp. & Age & -0.8817 & $0.006^{* *}$ & 0.04 \\
\hline
\end{tabular}

Age = edge age; ED = edge density within $300 \mathrm{~m}$ buffer from plot; F-area = the proportion of forest area in a $500 \mathrm{~m}$ radius circle with plot at the center.

${ }^{*} \mathrm{p}<0.05$.

$\mathrm{p}<0.01$.

percentage of forest area. In terms of edge age, F3 contains the oldest forest edges (17.7 years old) followed by F5 (14.6 years old).

In contrast to the comparison with burned forests, differences in forest AGB and stem density within the unburned forest fragments were subtle. Except for stems with DBH $10-20 \mathrm{~cm}$ size, where F3 was significantly distinct from F1 and F2 in stem density ( $p<0.05$ and $p<0.01$, respectively), AGB differences between F3 and F2, and F3 being distinct from F1 and F2 in total stem density ( $p<0.05$ and $p<0.01$, respectively), no difference was recorded in AGB or tree density among forest fragments across different stem sizes (Fig. 6). Overall, F3, the oldest forest fragment with the oldest edge age (Table 4), showed the lowest AGB and stem density up to DBH $20-30 \mathrm{~cm}$ size. These forest fragments present high variability among plots indicated by high standard deviations. In terms of pioneer species, high densities of pioneer species were found in F3 and $\mathrm{F} 5$, the oldest and most fragmented sites respectively. But F1, the least fragmented site, also presented the same level of density. Overall, very small portions of pioneer species were found in fragmented forests: 4.5\% (F1), 2.2\% (F2), 4.2\% (F3), 3.1\% (F4) and 3.5\% (F5). The highest relative portion of Cecropia sp. within pioneer species was found in F2 followed by F5 (37.14\%), and F1 (24\%) (Table 5).

\subsection{Drivers of change in forest $A G B$ and structure}

Within all plots sampled in unburned forest fragments, edge age and edge density were selected in the best-fit model by GLMM for AGB DBH $\geq 10 \mathrm{~cm}$ but weakly contributed to explaining AGB, i.e., $r^{2}=0.09$, and were negatively associated with change in AGB $\mathrm{DBH} \geq 10 \mathrm{~cm}$ (Table 6, Fig. 7). No significant predictor for small stems (DBH $<10 \mathrm{~cm}$ ) AGB was identified (Table 6), however, slope showed the largest importance value (Table 7). As for stem density, edge age and forest area were good predictors of large stem density $(\mathrm{DBH} \geq 10 \mathrm{~cm})$, whereas edge age was a highly significant predictor of smaller stem density, followed by slope and elevation (Table 6). Overall, edge age was the most important variable for large tree AGB and stem density and the second most important variable for small stem density (Table 7). Edge density and forest area within fragmentation variables had high importance values for large stem AGB and density, respectively. On the other hand, edge distance, one of the most important drivers of disturbed forests in previous studies, presented no significant contribution to changes in forest structure and biomass. Edge age again was one of the most important variables to AGB and structure of pioneer species except $\mathrm{DBH}>10 \mathrm{~cm}$. F-area and edge density were also significantly important for AGB of $\mathrm{DBH} \geq 10 \mathrm{~cm}$. Edge distance was one of the most important variables for the best model of stem density of $\mathrm{DBH} \geq 10 \mathrm{~cm}$ of Cecropia sp.

In terms of relative change in AGB along edge distance, Fig. 8 shows that $70 \%$ of plots show negative relative change in AGB along the edge distance up to $400 \mathrm{~m}$ at fragment scale, but these changes are poorly correlated with edge distance $\left(r^{2}=0.03\right)$.

\section{Discussion}

\subsection{Forest recover from fire}

Our results of burned forests in 2005 (9 years after the event) and 2010 (4 years after the event) indicated a rapid forest recovery from fire. While the most recently burned forest was distinct from unburned forest in AGB DBH $\geq 10 \mathrm{~cm}(p<0.01)$ and stem density $\mathrm{DBH}<10 \mathrm{~cm}(p<0.01)$, no significant difference of forest AGB of the 2005 burned forest from the 2010 and unburned forest area exists. In terms of stem density of $\mathrm{DBH} \geq 10 \mathrm{~cm}$, these sampled areas were statistically similar. Our results are consistent with Sato et al. (2016) in showing rapid forest AGB recovery after the 2005 and the 2010 burn events in eastern Acre, including the Bonal Reserve. However, they observed significant differences among unburned forest and burned forests in 2005 and 2010 in AGB and canopy height as estimated from airborne LiDAR data covering much larger areas than forest inventory plots (Sato et al., 2016). Barlow et al. (2012) found more limited impacts of forest fire on forests three years after the 2005 wildfire event in Acre on stem density $<10 \mathrm{~cm} \mathrm{DBH}$, whereas forest live AGB $>10 \mathrm{~cm} \mathrm{DBH}$ from burned forests were indistinguishable from those in unburned forests. In our case, four year-old burned forests in 2010 were still distinct from unburned forests in these two measurements. These different results between Barlow et al. (2012) and our study are likely associated with differences in fire intensity, which affects subsequent forest recovery (Cochrane and Schulze, 1999; Barlow et al., 2003).

In general, positive relationships between aboveground carbon pools and the time since the last fire event have been observed (Berenguer et al., 2014). However, forest biomass loss can continue a few years after a fire event as Barlow and Peres (2008) observed, with declines in the stem density in both the small $(10-20 \mathrm{~cm}$ DBH) and large ( $\geq 50 \mathrm{~cm}$ DBH) between 1 and 3 years after fire and strong recruitment into the $10-20 \mathrm{~cm}$ DBH size classes between 3 and 9 years post-fire. In our study, the highest tree mortality in the 2005 burned forest would potentially indicate a long term increase in mortality beyond 4 years. Both Cochrane and Schulze (1999) and Barlow et al. (2003) showed such effects out to 3 years in the Eastern Amazon. It is either killing large trees that are standing a long time or creating ongoing mortality of mid-sized trees, likely from a combination of damage and environmental stress. A potential cause of this long-term mortality, besides the prolonged effects of fire, is the 2010 drought that may have strongly influenced tree mortality and the recovery of forest burned in 2005. No human impacts in the 2005 burned forest were observed in the field.

Higher amounts of pioneer species in burned areas compared to unburned forests found in this study (Tables 2 and 3) indicate tree 

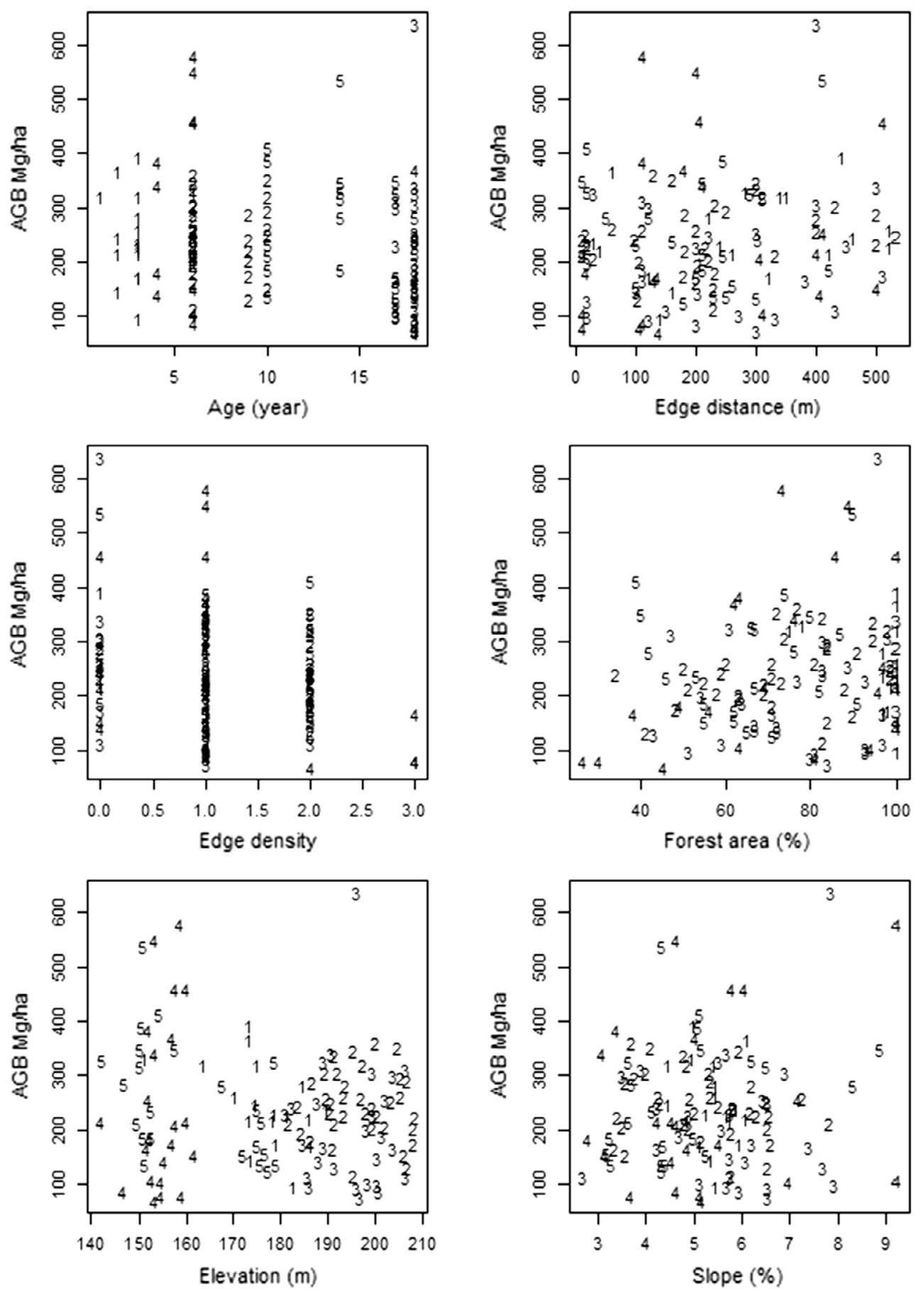

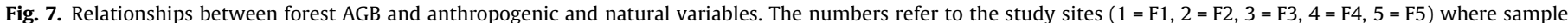
plots were measured.

community turnover after fire, which agrees with the literature (Cochrane and Schulze, 1999; Barlow and Peres, 2008). Stem density of Cecropia sp. across the study classes clearly indicated the forest composition recovery process from fire with high density of small stem $(\mathrm{DBH}<10 \mathrm{~cm})$ in the recent fire event, and high density of larger stems in the 2005 burned forest plots.

\subsection{Forest fragmentation}

Fragmentation effects did not seem to substantially affect forest AGB and stem density in our study area in Acre. Among the fragmentation variables, edge age was the strongest driver for large tree AGB and density changes of both trees and Cecropia sp. in our analysis (Table 6). This variable was negatively associated with AGB and stem density indicating that AGB and stem density decreased as forest edges remained longer in the landscape. According to previous findings, the most intense biomass collapse, due to edge effects, occurs during the first years after forest fragmentation before forests reach a new equilibrium (Laurance et al., 1997). In our case, loss of trees in fragmented forests seems to have occurred over a longer period. F3, the oldest edge age (17.7 years), presents the lowest AGB and stem density (Fig. 6). The oldest age in this study was 18 years old based upon our land cover time series dataset, but many plots within $\mathrm{F} 3$ may potentially 
Table 7

Relative importance of fragmentation and environmental variables in determining differences in AGB and structure of the studied forests.

\begin{tabular}{lllll}
\hline & AGB & AGB & Stem density & Stem density \\
DBH $\geq 10 \mathrm{~cm}$ & DBH $<10 \mathrm{~cm}$ & $\begin{array}{l}\mathrm{DBH} \geq 10 \mathrm{~cm} \\
\mathrm{DBH}\end{array}$ & & \\
\hline Tree & & & & 0.52 \\
Age & 0.67 & 0.27 & 0.90 & 0.31 \\
Distance & 0.28 & 0.27 & 0.28 & 0.28 \\
ED & 0.53 & 0.27 & 0.33 & 0.39 \\
F-area & 0.39 & 0.26 & 0.69 & 0.45 \\
Elevation & 0.38 & 0.25 & 0.26 & 0.91 \\
Slope & 0.26 & 0.33 & 0.25 & \\
Cecropia $\mathrm{sp}$. & & & 0.84 \\
Age & 0.26 & 0.64 & 0.62 & 0.28 \\
Distance & 0.27 & 0.37 & 0.58 & 0.43 \\
ED & 0.88 & 0.37 & 0.48 & 0.49 \\
F-area & 0.96 & 0.34 & 0.84 & 0.25 \\
Elevation & 0.27 & 0.27 & 0.26 & \\
Slope & 0.26 & 0.25 & 0.25 &
\end{tabular}

Age = edge age; ED = edge density within $300 \mathrm{~m}$ buffer from plot; F-area = the proportion of forest area in a $500 \mathrm{~m}$ radius circle with plot at the center.

belong to forest edges older than this. A longer edge exposure time increases the risks of repeated anthropogenic disturbances such as logging and forest fires, which result in large net losses of forest AGB over time. Edge density and forest area were secondary important variables. They contributed to AGB change marginally. Edge density that indicates effects of multiple edges contributed to the reduction of forest AGB and stem density and therefore negatively related to forest measures, while forest area is positively related with forest AGB and stem density (Table 6 and Fig. 7).

Regarding environmental variables, increasing slope was a significant and most important predictor of stem density of small trees with $\mathrm{DBH}<10 \mathrm{~cm}$ according to GLMM analysis. Slope effects on forest structure, e.g., higher stem density of trees or sapling on slopes compared to flat sites, have been observed in the literature (Denslow, 1995; Clark and Clark, 2000). Slopes in our study areas, however, are gentle, varying between $2.6 \%$ and $9.0 \%$. One potential explanation for this result is that slope may increase light penetration through the forest canopy, improving light conditions conducive to plant growth, especially understory plants that are more sensitive to light conditions. This, however, depends upon slope orientation or aspect (Auslander et al., 2003). In the southern hemisphere, north-facing slopes receive greater solar radiation than south-facing slopes. Another possible explanation is slope may improve drainage of surface water and contribute to plant growth. Both potential impacts (aspect and hydrology) of slope on tree growth need to be addressed in future studies specifically designed to quantify these effects.

There was high spatial variability of AGB and stem density along edge distances up to $500 \mathrm{~m}$ at each site making edge distance a poor predictor for forest AGB and tree density dynamics in the studied fragments based upon our GLMMs analysis. Forest biomass collapse has been confirmed near forest edges in previous studies, especially within $100 \mathrm{~m}$ (Laurance et al., 1997; Armenteras et al., 2013; Berenguer et al., 2014; Brando et al., 2014; Benchimol and Peres, 2015). However, Phillips et al. (2006) observed no significant biomass losses associated with edge distance in fragmented forests in the southwestern Amazon, agreeing with our results. High variability of AGB existed even within $100 \mathrm{~m}$ (Fig. 7). There are some potential explanations for these different results. First, $25 \times 25 \mathrm{~m}$ ( 0.0625 ha) plot size is probably not adequate to capture representative spatial variability of forest structure and biomass. Many studies have employed plot sample sizes of $0.25-1$ ha (Laurance et al., 1997; Berenguer et al., 2014; Benchimol and Peres, 2015). Second, our results may be attributed to higher soil fertility in the southern Amazon than in the central and eastern Amazon, affecting forest AGB recovery from disturbance (Malhi et al., 2004; Phillips et al., 2006). While soil types are similar over our study areas, predominantly covered with Argisols (Amaral, 2006), our analysis lacked a soil chemical and physical analysis to better understand how it may be affecting forest AGB and structure change within fragmented forests. Soils should be considered in future studies.

In our analysis, one unknown factor potentially affecting forest fragmentation-related changes was selective logging. This activity, often practiced by landowners, legally or illegally, extracts trees with high commercial value and/or for construction purposes. Even in F1, the least fragmented area, some large trees have been extracted, as its being a sustainable development reserve. Unfortunately, we were not able to include this

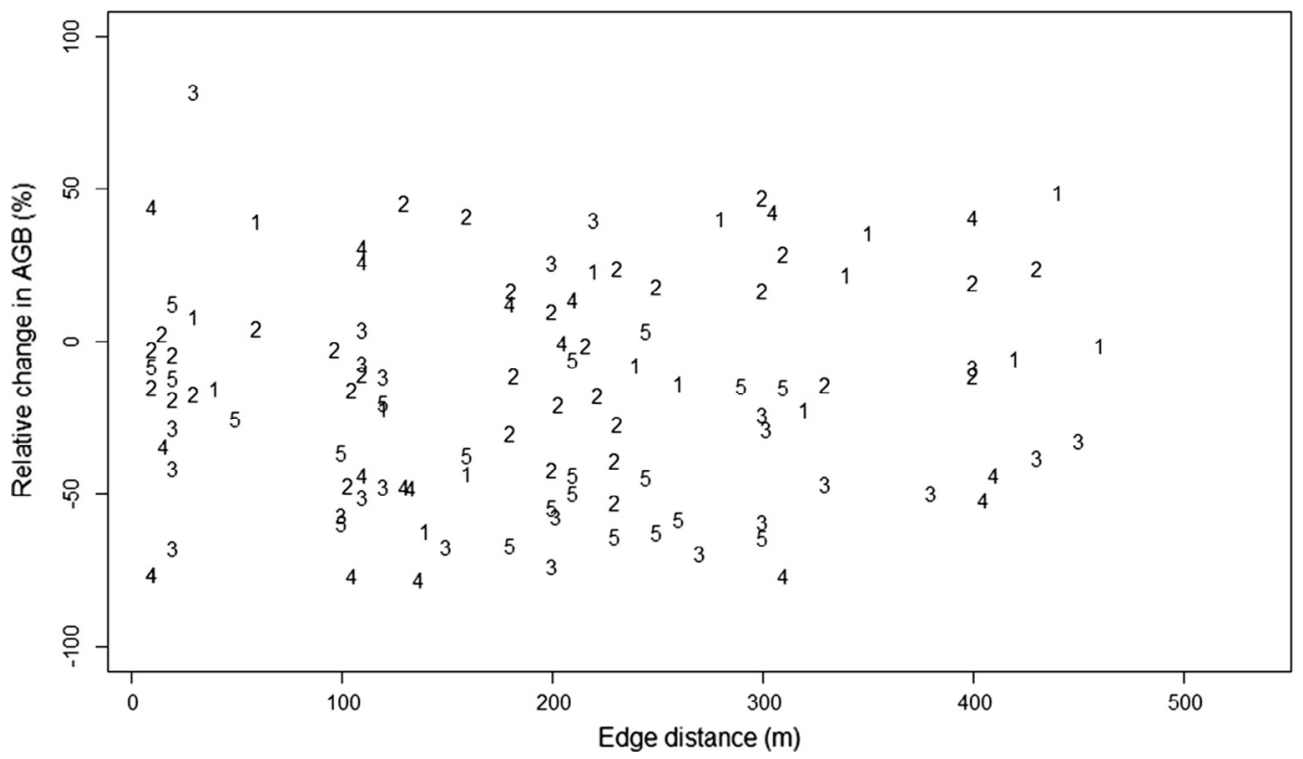

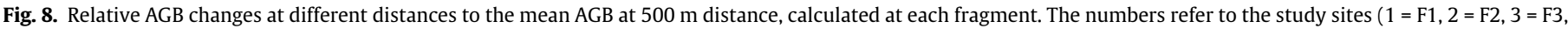
$4=\mathrm{F} 4,5=\mathrm{F} 5$ ) where sample plots were measured. 
factor due to the absence of accurate historical data on logging in the region. Repeated post forest fragmentation disturbances produced by human activities should ideally be addressed in future assessments of edge effects.

Because of recent deforestation rate reductions in the Amazon, degraded forests and their drivers have gained more importance in the Amazon (Nepstad et al., 2008; Davidson et al., 2012) and understanding the effects of disturbances on tropical forests is critical for better forest management. Given highly fragmented forest ecosystems and more frequent occurrence of drought in southwestern Amazonia, the effects of forest fragmentation and forest fire associated with drought in open and seasonal forests need to be better understood.

\section{Conclusions}

We studied impacts of forest fire and fragmentation on forests separately in highly fragmented landscapes in the southwestern Amazon state of Acre. Our results of forest biophysical dynamics in Acre added tropical forest responses to fire and fragmentation. Limited edge effects were observed on AGB and tree density in the studied sites. Among fragmentation variables, edge age was the most important predictor of AGB and structure changes in forests due to forest fragmentation, followed by edge density. Although AGB change and edge distance were poorly correlated, relative change of forest $A G B$ at different edge distances indicates substantial reduction of $A G B$ up to $400 \mathrm{~m}$ of edge distance.

While the impact of forest fire four years after the event is still significant on AGB and stem density, as compared with unburned forest, we observed forest AGB recovery nine years after the 2005 fire event. The 2010 burned forest plots had the number of pioneer species, AGB and densities of small stems of Cecropia sp. significantly higher than unburned forests. The 2005 burned forest plots showed higher density of large stems compared to unburned forests.

\section{Acknowledgments}

This work was supported by a research grant from the NASA Terrestrial Ecology Program (NNH13ZDA001N-TE). The authors acknowledge Marcio Sales for his valuable suggestions.

\section{References}

Acre, 2010. Zoneamento Ecológico-Econômico do Estado do Acre: Fase II (Escala 1:250.000). SEMA, Rio Branco.

Amaral, E.F., 2006. Relatório sobre Solos do Estado do Acre. Solos do Acre. SEMA/ IMAC, Rio Branco.

Alencar, A.A., Brando, P.M., Asner, G.P., Putz, F.E., 2015. Landscape fragmentation, severe drought, and the new Amazon forest fire regime. Ecol. Appl. 25, 1493 1505.

Andersen, H.E., Reutebuch, S.E., McGaughey, R.J., d'Oliveira, M.V.N., Keller, M., 2013. Monitoring selective logging in western Amazonia with repeat lidar flights. Remote Sens. Environ. http://dx.doi.org/10.1016/j.rse.2013.08049.

Aragao, L.E.O.C., Poulter, B., Barlow, J.B., Anderson, L.O., Malhi, Y., Saatchi, S., Phillips, O.L., Gloor, E., 2014. Environmental change and the carbon balance of Amazonian forests. Biol. Rev. 89, 913-931.

Aragao, L.E.O.C., Malhi, Y., Roman-Cuesta, R.M., Saatchi, S., Anderson, L.O., Shimabukuro, Y.E., 2007. Spatial patterns and fire response of recent Amazonian droughts. Geophys. Res. Lett. 34.

Arima, E.Y., Barreto, P., Araujo, E., Soares, B., 2014. Public policies can reduce tropical deforestation: lessons and challenges from Brazil. Land Use Policy 41, 465-473.

Armenteras, D., Gonzalez, T.M., Retana, J., 2013. Forest fragmentation and edge influence on fire occurrence and intensity under different management types in Amazon forests. Biol. Cons. 159, 73-79.

Auslander, M., Nevo, E., Inbar, M., 2003. The effects of slope orientation on plant growth, developmental instability and susceptibility to herbivores. J. Arid Environ. 55, 405-416.

Barlow, J., Silveira, J.M., Mestre, L.A.M., Andrade, R.B., D’Andrea, G.C., Louzada, J., Vaz-de-Mello, F.Z., Numata, I., Lacau, S., Cochrane, M.A., 2012. Wildfires in bamboo-dominated amazonian forest: impacts on above-ground biomass and biodiversity. PLOS ONE 7.

Barlow, J., Peres, C.A., 2008. Fire-mediated dieback and compositional cascade in an amazonian forest. Philos. Trans. R. Soc. B 363, 1787-1794.

Barlow, J., Peres, C.A., 2004. Ecological responses to El Nino-induced surface fires in central Brazilian Amazonia: management implications for flammable tropical forests. Philos. Trans. R. Soc. B - Biol. Sci. 359, 367-380.

Barlow, J., Peres, C.A., Lagan, B.O., Haugaasen, T., 2003. Large tree mortality and the decline of forest biomass following Amazonian wildfires. Ecol. Lett. 6, 6-8.

Benchimol, M., Peres, C.A., 2015. Edge-mediated compositional and functional decay of tree assemblages in Amazonian forest islands after 26 years of isolation. J. Ecol. 103, 408-420.

Berenguer, E., Ferreira, J., Gardner, T.A., Aragao, L.E.O.C., De Camargo, P.B., Cerri, C.E., Durigan, M., De Oliveira, R.C., Vieira, I.C.G., Barlow, J., 2014. A large-scale field assessment of carbon stocks in human-modified tropical forests. Glob. Change Biol. 20, 3713-3726.

Brando, P.M., Balch, J.K., Nepstad, D.C., Morton, D.C., Putz, F.E., Coe, M.T., Silverio, D., Macedo, M.N., Davidson, E.A., Nobrega, C.C., Alencar, A., Soares, B.S., 2014. Abrupt increases in Amazonian tree mortality due to drought-fire interactions. Proc. Natl. Acad. Sci. USA 111 (17), 6347-6352.

Clark, D.B., Clark, D.A., 2000. Landscape-scale variation in forest structure and biomass in a tropical rain forest. For. Ecol. Manage. 137, 185-198.

Cochrane, M.A., Laurance, W.F., 2008. Synergisms among fire, land use, and climate change in the Amazon. Ambio 37, 522-527.

Cochrane, M.A., Schulze, M.D., 1999. Fire as a recurrent event in tropical forests of the eastern Amazon: effects on forest structure, biomass, and species composition. Biotropica 31 (1), 2-16.

Cumming, G.S., Southworth, J., Rondon, X.J., Marsik, M., 2012. Spatial complexity in fragmenting Amazonian rainforests: do feedbacks from edge effects push forests towards an ecological threshold? Ecol. Compl. 11, 67-74.

Davidson, E.A., Davidson, E.A., de Araujo, A.C., Artaxo, P., Balch, J.K., Brown, I.F., Bustamante, M.M.C., Coe, M.T., DeFries, R.S., Keller, M., Longo, M., Munger, J.W., Schroeder, W., Soares, B.S., Souza, C.M., Wofsy, S.C., 2012. The Amazon basin in transition. Nature 481 (7381), 321-328.

Denslow, J.S., 1995. Disturbance and diversity in tropical rain-forests - the density effect. Ecol. Appl. 5, 962-968.

d'Oliveira, M.V.N., Reutebuch, S.E., McGaughey, R.J., Andersen, H.E., 2012. Estimating forest biomass and identifying low-intensity logging areas using airborne scanning lidar in Antimary State Forest, Acre State, Western Brazilian Amazon. Remote Sens. Environ. 124, 479-491.

d'Oliveira, M.V.N., Ribas, L.A., 2011. Forest regeneration in artificial gaps twelve years after canopy opening in Acre State Western Amazon. For. Ecol. Manage. $261,1722-1731$

Ewers, R.M., Thorpe, S., Didham, R.K., 2007. Synergistic interactions between edge and area effects in a heavily fragmented landscape. Ecology 88, 96-106.

Goodman, R.C., Phillips, O.L., Torres, D.D., Freitas, L., Cortese, S.T., Monteagudo, A., Baker, T.R., 2013. Amazon palm biomass and allometry. For. Ecol. Manage. 310, 994-1004.

Hoorn, C., Wesselingh, F.P., ter Steege, H., Bermudez, M.A., Mora, A., et al., 2010. Amazonia through time: Andean uplift, climate change, landscape evolution, and biodiversity. Science 330, 927-931.

Laurance, W.F. et al., 2011. The fate of Amazonian forest fragments: a 32-year investigation. Biol. Cons. 144 (1), 56-67.

Laurance, W.F., Nascimento, H.E.M., Laurance, S.G., Andrade, A., Ribeiro, J.E.L.S., Giraldo, J.P., Lovejoy, T.E., Condit, R., Chave, J., Harms, K.E., D’Angelo, S., 2006. Rapid decay of tree-community composition in Amazonian forest fragments. Proc. Natl. Acad Sci. U.S.A. 103, 19010-19014.

Laurance, W.F., Laurance, S.G., Ferreira, L.V., RankindeMerona, J.M., Gascon, C., Lovejoy, T.E., 1997. Biomass collapse in Amazonian forest fragments. Science 278, 1117-1118.

Lewis, S.L., Brando, P.M., Phillips, O.L., van der Heijden, G.M.F., Nepstad, D., 2011. The 2010 Amazon drought. Science 331, 554.

Lovejoy, T.E., Bierregaard Jr., R.O., Rylands, A.B., Malcolm, J.R., Quintela, C.E., Harper, L.H., Brown Jr., K.S., Powell, A.H., Powell, G.V.N., Soule, M.E. 1986. Edge and other effects of isolation on Amazon forest fragments. Conserv. Biol. The science of scarcity and diversity, 257-285.

Malcolm, J.R., 1994. Edge effects in central Amazonian forest fragments. Ecology 75 2438-2445.

Malhi, Y., Aragao, L.E.O.C., Metcalfe, D.B., Paiva, R., Quesada, C.A., Almeida, S., Anderson, L., Brando, P., Chambers, J.Q., da Costa, A.C.L., Hutyra, L.R., Oliveira, P., Patino, S., Pyle, E.H., Robertson, A.L., Teixeira, L.M., 2009. Comprehensive assessment of carbon productivity, allocation and storage in three Amazonian forests. Glob. Change Biol. 15, 1255-1274.

Malhi, Y., Baker, T.R., Phillips, O.L., Almeida, S., Alvarez, E., Arroyo, L., Chave, J., Czimczik, C.I., Di Fiore, A., Higuchi, N., Killeen, T.J., Laurance, S.G., Laurance, W.F., Lewis, S.L., Montoya, L.M.M., Monteagudo, A., Neill, D.A., Vargas, P.N., Patino, S., Pitman, N.C.A., Quesada, C.A., Salomao, R., Silva, J.N.M., Lezama, A.T., Martinez, R.V., Terborgh, J., Vinceti, B., Lloyd, J., 2004. The above-ground coarse wood productivity of 104 Neotropical forest plots. Glob. Change Biol. 10, 563-591.

Nelson, B.W., Mesquita, R., Pereira, J.L.G., de Souza, S.G.A., Batista, G.T., Couto, L.B., 1999. Allometric regressions for improved estimate of secondary forest biomass in the central Amazon. For. Ecol. Manage. 117, 149-167.

Nepstad, D.C., Stickler, C.M., Soares, B., Merry, F., 2008. Interactions among Amazon land use, forests and climate: prospects for a near-term forest tipping point. Philos. Trans. R. Soc. B - Biol. Sci. 363, 1737-1746. 
Nogueira, E.M., Fearnside, P.M., Nelson, B.W., Barbosa, R.I., Keizer, E.W.H., 2008. Estimates of forest biomass in the Brazilian Amazon: new allometric equations and adjustments to biomass from wood-volume inventories. For. Ecol. Manage. 256 (11), 1853-1867.

Numata, I. Cochrane, M.A. 2012. Forest fragmentation and its potential implications in the Brazilian Amazon between 2001 and 2010. Open J. For. 2 (4), 265-271.

Numata, I., Cochrane, M.A., Souza, C.M., Sales, M.H., 2011. Carbon emissions from deforestation and forest fragmentation in the Brazilian Amazon. Environ. Res. Lett. 6.

Numata, I., Cochrane, M.A., Roberts, D.A., Soares, J.V., 2009. Determining dynamics of spatial and temporal structures of forest edges in South Western Amazonia. For. Ecol. Manage. 258 (11), 2547-2555.

Phillips, O.L., Rose, S., Mendoza, A.M., Vargas, P.N., 2006. Resilience of southwestern Amazon forests to anthropogenic edge effects. Conserv. Biol. 20 (6), 1698-1710.

Sato, L.Y., Gomes, V.C.F., Shimabukuro, Y.E., Keller, M., Arai, E., Nara dos-Santos, M., Brown, I.F., de Aragao, L.E.O.E.C., 2016. Post-fire changes in forest biomass retrieved by airborne LiDAR in Amazonia. Rem. Sens. 8, 10.
Scatena, F.N., Silver, W., Siccama, T., Johnson, A., Sanchez, M.J., 1993. Biomass and nutrient content of the Bisley Experimental Watersheds, LuquilloExperimental-Forest, Puerto-Rico, before and after Hurricane-Hugo, 1989 Biotropica 25, 15-27.

Souza, C.M. Siqueira, J.V., Sales, M.H., Fonseca, A.V., Ribeiro, J.G. Numata, I., Cochrane, M.A., Barber, C.P., Roberts, D.A., Barlow, J., 2013. Ten-year landsat classification of deforestation and forest degradation in the Brazilian Amazon. Rem. Sens. 5 (11), 5493-5513.

Tasker, K.A., Arima, E.Y., 2016. Fire regimes in Amazonia: the relative roles of policy and precipitation. Anthropocene 14, 46-57.

Uhl, C., Buschbacher, R., Serrão, E.S.A., 1988. Abandoned pasture in eastern Amazonia I. Patterns of plant succession. J. Ecol. 76, 663-681.

Xaud, H.A.M., Martins, F.D.R.V., dos Santos, J.R., 2013. Tropical forest degradation by mega-fires in the northern Brazilian Amazon. For. Ecol. Manage. 294, 97-106.

Zuur, A.F., Ieno, E.N., Walker, N., Saveliev, A.A., Smith, G.M., 2009. Mixed Effects Models and Extensions in Ecology with R. Springer, New York, NY, USA. 